\title{
Chapter 8: Complaining in the Age of Consumption: Patients, Consumers or
}

\section{Citizens?}

\section{Alex Mold}

In January 1984, a patient named Michael was taken seriously ill with kidney failure.

Following dialysis, he developed an infection that required treatment with antibiotics.

Michael told the doctor treating him that in the past he had reacted badly to penicillin, but he was prescribed the drug nonetheless. Michael developed what he called 'the mother and father of all rashes', which kept him in hospital for a further five weeks. Michael reported that:

Afterwards, I asked, 'I said that I was sensitive to penicillin; why did you give it to me?' The answer was, 'Oh well, old boy, it was the best antibiotic for your particular infection and we thought that we could take the chance.' Whose chance? Whose life? Whose body? Who is the sufferer? What is the compensation? What is the complaints procedure? There appears to be no such procedure. The patient is just the fall guy who is in the hands of doctors who think that they know better than the patient. ${ }^{1}$

Michael's compliant might have fallen on deaf ears were it not for the fact the he was Michael McNair-Wilson, Conservative MP for Newbury, England. Though he was unfortunate to have been so unwell, in 1985 McNair-Wilson was lucky enough to have his name drawn in a parliamentary procedure known as the 'members' ballot', allowing him the opportunity to put forward a piece of legislation. McNair-Wilson took up the issue of patient rights, and the right to complain in particular. His draft Hospital Complaints Procedure Bill proposed the requirement that all hospitals establish a complaints procedure. The Bill was discussed in the House of Commons in February 1985. The Under-Secretary of State for Health, John Patten, responded favourably to the Bill, stating that 'It should make a real contribution towards the 
provision of a more consumer-responsive NHS. ${ }^{2}$ Such a statement suggested that the ability to complain was being linked to the development of a more consumerorientated NHS, but to what extent was complaining about medicine different in an age of consumption?

Complaining about health care, as the chapters in this volume demonstrate, was nothing new. People probably always have, and always will be dissatisfied with aspects of their medical treatment and want to make this dissatisfaction known. This was achieved through the types of internal procedures outlined in the Introduction and by Thomson and Sanz; through the peri-public spaces of Price and King; the courtrooms and inquiries of Wall and McHale; the debates and critiques of Ingram, Scull and Cook; and the media attention discussed by Newsom Kerr and throughout this collection. Yet, from the late 1960s onwards, the re-imagining of the patient as a consumer changed ideas about medical complaints. The ability to complain was a crucial issue in both the construction of the patient as a consumer and in the development of patient-consumer activism. This chapter will explore the ways in which complaining about medicine was different in Britain during the second half of the twentieth century. This period was an age of consumption, where consumerist ideas and approaches were applied to all spheres of life, including public services like health care. The implications of such a development for the issue of complaining about medicine can be observed in three areas: first, the centrality of complaint to the notion of the patient-consumer; second, the conceptualisation of complaining as a right; and finally, the development of formal complaints procedures. This chapter will suggest that complaining played a crucial part in the construction of the patient as consumer, but complaining was a somewhat ineffective tool for groups aiming to represent the patient-consumer. Difficulties around establishing complaint as a right, 
and the long delay surrounding the introduction of formal complaints procedures, point to much more fundamental issues with the whole notion of the patient as consumer.

\section{Complaint and the patient-consumer}

Although patients could be said to have operated as 'consumers' in the medical market-place in Britain that predated the establishment of the National Health Service (NHS) in 1948, and patients were afforded some say in the way medical services were managed through mechanisms such as contributory schemes - as highlighted by Thompson and Sanz's chapters - this kind of patient involvement was not generally referred to in the language of consumption. ${ }^{3}$ Specific engagement with the idea that patients were 'consumers' of health care only began to occur in the latter half of the twentieth century, as the proliferation of consumer goods and the development of the organised consumer movement started to have an impact on the delivery of public services. In the early 1960s, a handful of health economists such as D. S. Lees began to use the term 'consumer' in connection with health, as did think tanks and consumer groups such as Political and Economic Planning (PEP) and the Research Institute for Consumer Affairs. ${ }^{4}$ An editorial in the Lancet in 1961 was moderately supportive, noting that: "Emphasising the "consumer point of view" can be very valuable because undoubtedly patients have suffered in the past from having no means of judging the medical services and little or no means of addressing them. ${ }^{5}$

The language of consumption was able to enter the health care arena partly because consumerist principles were beginning to proliferate within public services more widely. In the early twentieth century, consumer identity was tied to the 
development of welfare politics and social citizenship, but by the middle of the century, the 'citizen consumer' and the 'rational consumer' came into being. ${ }^{6}$ During the 1950s, the development of an organised consumer movement concerned with consumers' rights and comparative testing moved consumption 'beyond things', to consider public, as well as private, goods and services. ${ }^{7}$ Moreover, consumerism offered a tool for activists to right the wrongs of contemporary health care as they saw them. ${ }^{8}$ Although satisfaction with the NHS at this time was still high - in 1961 PEP found that $86 \%$ of families were satisfied with the attention given to them by their GP - medical care was not seen as infallible. Waning faith in the ability of biomedicine to conquer all ills and a series of high-profile scandals, such as that around thalidomide and the human guinea pig revelations about experiments being conducted on NHS patients, along with a host of other controversies outlined in the Introduction to this volume, undermined confidence in medicine and the medical profession. ${ }^{9}$

Patient-consumer organisations were set up (at least in part), to improve the situation around patient complaints. Helping patients to complain, informing people of the correct procedures and dealing with specific complaints, as well as campaigning for improvements in complaints mechanisms, were key areas of activity for such groups. A specific complaint - about the use of patients in NHS hospitals in research without their knowledge or consent - was the motivation behind the creation of the Patients Association (PA) in 1962. Helen Hodgson, a teacher, was moved to set up the organisation by 'reports on thalidomide babies, wrong patient operations and tests on patients'. ${ }^{10}$ The Association, however, rapidly found itself dealing with a broad range of issues relating to complaints. In its first 18 months of existence, the PA received 525 complaints from patients. ${ }^{11}$ The PA did not take up individual 
complaints, but they did advise people on whether they were likely to have a case and how to negotiate the various levels of complaints procedure.

The Community Health Councils (CHCs) performed a similar function. Created in 1974 through the reorganisation of the NHS, 207 CHCs were established at the local level to be the 'voice of the consumer' within the health service. ${ }^{12}$ One of their statutory roles was to act as the 'patient's friend' and assist patients in making complaints. Although all CHCs received complaints, the volume of complaints that they dealt with varied widely from council to council and changed over time. For its first three months of existence, one $\mathrm{CHC}$ reported receiving 22 complaints, whilst others reported 'minimal' complaints in their early years. ${ }^{13}$ Yet, by the 1980 s, South Birmingham $\mathrm{CHC}$ reported that complaints work took up about a quarter of the Council's time, and a study of CHCs by a firm of management consultants in the 1990s found that councils spent $50 \%$ of their time dealing with complaints. ${ }^{14}$

Although complaints work was time consuming, complaints were a useful source of information for patient-consumer organisations about the state of the NHS. Some attempt was made to analyse the complaints received by groups like the PA and the CHCs in order to point to wider failings in NHS care. In 1964, the PA reported that of the complaints they had received, $21 \%$ were about negligence, but over a third concerned what Helen Hodgson termed 'attitude to patients', including bad organisation, lack of communication, 'inhumanity' and discourtesy. ${ }^{15}$ The PA tried to conduct a more formal analysis of complaints in the mid-1970s with the help of the Consumers' Association, but this project never got off the ground. ${ }^{16}$ As Glen O'Hara points out, in the 1960s and 1970s there was a lack of information about complaints and their handling. Little work had been done on categorising different types of complaint or using these to determine broader patterns. ${ }^{17}$ One $\mathrm{CHC}$ examined the 
complaints that it had received in its first year of activity and found that these could be placed in three categories. In language reminiscent of Klein's classic study and picked up on in Clarke's afterword, the first was 'grumbles, comments and suggestions'; these required no specific action. ${ }^{18}$ The second was 'expressions of distress and dissatisfaction'; these were usually dealt with informally. Finally, there were 'protests, grievances or accusations'; these were more formal complaints that required referral to the relevant authority. ${ }^{19}$

Analysing complaints, even in this rather crude way, demonstrated to patientconsumer organisations the significance and value of complaints at both an individual and collective level. In their 1974 handbook for CHCs, Jack Hallas and Bernadette Fallon argued that helping patients with complaints was 'one of the most important aspects of community health council work.' Aiding individuals who were less able to make their dissatisfaction known, whom they termed 'submerged groups', was particularly vital. In this way, Hallas and Fallon suggested, CHCs could act as an 'early warning system', bringing the Area Health Authority's attention to potential causes for dissatisfaction. ${ }^{20}$ Patient-consumer groups were well aware that formal complaints were only the tip of 'the iceberg'. ${ }^{21}$ Elizabeth Stanton, writing in the National Consumer Council's (NCC) magazine, the Clapham Omnibus, stated that 'Most patients are grateful for any good done to them by the National Health Service, and are reluctant to complain formally if things go wrong'. But, she noted, 'consumer activists have realised for some years that this "gratitude barrier" is unhealthy not only for patients and their families but also for the medical profession and the NHS itself.' $^{22}$

Complaints, patient-consumer groups suggested, operated as indicators of the quality of services being provided. Jean Robinson of the PA urged the CHCs to use 
complaints to "make rational assessments of the quality of care. ${ }^{23}$ According to the editor of CHC News, Ruth Levitt, complaints were rarely isolated incidents; it was possible to generalise from specific misfortune and so advocate for wider change. ${ }^{24}$ This was a view later echoed by the 1979 Royal Commission on the NHS, which established that there was a 'need to develop an effective role for CHCs, not simply as an aid to complainants, but on the much wider front of influencing health service provision to meet the needs of patients. ${ }^{25}$

By the mid 1970s, it was evident that patient-consumer organisations had two key roles with respect to complaints. The first consisted of assisting patients to make complaints and offer practical support and guidance on complaints procedures. The second was about using complaints in a broader sense as a means to highlight deficiencies in the NHS and campaign for improvements. To perform both of these roles more effectively, patient-consumer groups marshalled the language of patients' rights in order to campaign for the establishment of a formal right to complain.

\section{The 'right' to complain}

Three distinct, but overlapping, visions of health rights were articulated in Britain during the second half of the twentieth century: health as a human right, as a citizen's right, and as a consumer's right. The notion that health is a fundamental human right - that it is a right that individuals possess simply by being born - is almost as old as the notion of human rights itself. Most commentators place the 'invention' of human rights in the eighteenth century, and although the right to health was not amongst the initial rights established by the French National Assembly, it was added to the list of the State's obligations to its citizens by the Constituent Assembly in $1791 .^{26}$ In 
Britain, there was no such bargain between the state and citizen, and it was not until the United Nations Universal Declaration of Human Rights in 1948 that the right to health was contemplated on a global level. The UN Declaration asserted that 'Everyone has the right to a standard of living adequate for health and well being of himself and his family, including food, clothing, housing and medical care. ${ }^{27}$ The right 'to the enjoyment of the highest attainable standard of physical and mental health' was also central to the establishment of the World Health Organization in 1946, and was enshrined in international law through the International Covenant on Economic, Social and Cultural Rights, which came into effect for member countries in $1976 .{ }^{28}$ During the 1970 s, the idea that health was a fundamental human right received added impetus from the Alma Ata Declaration on Primary Care in 1978, and through the international public health movement. ${ }^{29}$ Health as a human right became linked to development goals in the 1980s, and since the 1990s, to combating HIV/AIDS..$^{30}$

Although the notion of health as a human right was significant at the transnational level, in the UK the notion of rights in health took a rather different trajectory over this period. Instead of being concerned primarily with human rights, the rights discourse in Britain seemed to focus more on the rights of citizens. This could be partly explained by long-running discussions about individual rights within health in the UK. In the medical marketplace that pre-dated the NHS, patients had contractual and common-law rights relating to health care, as with other goods and services. ${ }^{31}$ Entitlement also lay at the heart of the gradual development of statesponsored health care in Britain up to and including the establishment of the NHS. The 1911 National Health Insurance Act (NHI) introduced compulsory health insurance for manual workers. In return for their financial contribution, members 
received benefit when sick and access to medical care without additional payment. Although, as Thompson points out elsewhere in this volume, such mechanisms could lead to friction, subscribers to hospital contributory schemes were entitled to some say in the way in which the institution was managed through representatives on hospital management committees. ${ }^{32}$

The coming of a collective system in the form of the NHS implied a more unified view of rights with respect to health. While the National Health Service Act (1946) was framed around the duty of the Minister of Health to provide a comprehensive service not the right of the patient to receive this, the message that reached the public emphasised universal entitlement. ${ }^{33}$ A leaflet distributed to all homes in 1948 asserted that the new service would 'provide you with all medical, dental and nursing care. Everyone - rich or poor, man, woman or child - can use it or any part of it. ${ }^{34}$ Underpinning such promises was the notion of social rights. For the sociologist T. H. Marshall, social rights permitted the citizen access to a minimum supply of essential social goods and services (such as medical attention, shelter and education), to be provided by the state. ${ }^{35}$ The NHS, and the other achievements of the 'classic' era of the British welfare state (1945 to 1975), appeared to offer a kind of social citizenship based on collective rights. ${ }^{36}$

Interwoven with ideas about the health rights of citizens was another set of expectations: the rights individuals could demand as consumers. The relationship between citizenship and consumption has been the subject of much research in recent years, and the activities of citizen-consumers can be detected as far back as the nineteenth century and beyond. ${ }^{37}$ But, by the middle of the twentieth century, citizen and consumer identities were becoming welded together more tightly. As discussed above, by the 1960s and 1970s, this approach had found purchase inside government. 
Organisations like the National Consumer Council (NCC) were created in 1975 to represent the consumer within public services. State-provided amenities from housing to health care were being discussed in increasingly consumerist terms. ${ }^{38}$ Consumer representation within the health service (in the form of the CHCs) was in line with the general trend towards the improvement of citizen-consumer representation, but here a particular language of entitlement around bodily autonomy was also in evidence. Although patients were supposed to give their consent to participate in medical trials (following the 1947 Nuremberg Code), this was widely ignored both in the UK and in the US. ${ }^{39}$ For Hodgson, founder of the PA, the key issue was that 'Patients are not told if they are receiving new or orthodox treatment. I maintain that they should be told. ${ }^{40}$ The patient, she asserted, 'is entitled to know what treatment, if any, he is receiving. ${ }^{41}$ The PA was therefore keen to establish the right of the patient to consent to all treatment, whether experimental or not.

The demand for bodily autonomy made by the PA echoed the kinds of rights claims made by the new social movements of this period. As the feminist historian Sheila Rowbotham commented, 'Rights were not abstract or about politics alone, they were active and about sex as well as economics. ${ }^{42}$ This wider conception of rights was crucial for dealing with the problems of 'quality of life, equality, individual selfrealization, participation and human rights,' representative, for German philosopher and sociologist Jürgen Habermas, of a 'new' form of politics. ${ }^{43}$ The rights claims of the 1960s and 1970s were thus a different kind of rights claim to that of the past, rooted not in transactional contracts and the market place, or in the social contract between state and citizen, but in the politics of everyday life. Rights discourse became a way in which groups claiming to speak on the behalf of patients could articulate new demands about bodily autonomy and individual self-determination. 
Rights claims were essential to the work of a number of groups that attempted to represent the patient as consumer in the latter half of the twentieth century. During the 1970s and 1980s, health consumer groups produced a range of guides to patients' rights. Publications included the Patients Association's Can I Insist? (1974), the Which? Guide to Your Rights (1980), a joint Consumers' Association/Patients Association publication, A Patients' Guide to the NHS (1983); the National Consumer Council's, Patients'Rights (1983); and the Association of Community Health Councils in England and Wales (ACHCEW), Patients' Charter (1986). ${ }^{44}$ Such a proliferation of documents listing patients' rights can be read in two ways. On the one hand, the abundance of charters points to the importance of the language of rights for patient groups, but on the other hand, the apparent need for these rights to be stated and re-stated in multiple publications would suggest that there was widespread ignorance about patients' rights.

In some ways, the large number of charters produced by patient organisations hinted at the fragility and dubious legality of many of the rights proposed. Despite claiming to be comprehensive guides to the rights that patients held, many of these publications confessed to confusion and uncertainty about the nature and legitimacy of patients' rights. The NCC stated that 'It is difficult to say precisely what health care patients are entitled to expect of the National Health Service (NHS). There are clues, but most of them are open to different interpretations, and circumstances greatly affect cases. ${ }^{45}$ This was partly because, as the CA observed in their guide to consumers' rights across a range of different services (both public and private) that 'There is no comprehensive list of rights which you can consult, nor is there any specific area of law that deals with them. Your rights are scattered among hundreds, perhaps thousands, of Acts of Parliament and secondary pieces of legislation [...] 
Sometimes your rights are not written down at all. They may exist because of custom and tradition, or merely because there is nothing saying that they are absent. ${ }^{46}$ Indeed, most of the rights listed in the various guides and charters had no, or little, legal basis. Patients' rights claims lacked a solid foundation: they needed procedures and changes in law and practice in order to establish these.

\section{The development of complaints procedures}

An opportunity to create a right to complain arrived in the 1970s and 1980s as attempts were made to introduce a unified complaints procedure in all hospitals. Systems were in place to deal with patient dissatisfaction (as discussed in the Introduction to this volume), but a number of developments contributed towards a sense that these were inadequate. Patients were able to complain about an individual doctor's conduct to the General Medical Council (GMC), but the GMC was not primarily a machine to handle patients' complaints, it was instead a regulatory body

for doctors. ${ }^{47}$ There was a process in place to deal with complaints made against General Practitioners (GPs): patients could complain to the Executive Councils, later Family Practitioner Committees, and have their case heard by the local Medical Service Committee, which acted as a judicial tribunal. ${ }^{48}$ However, there was no single system in place for complaints about treatment in hospital. Until 1966, when a Ministry of Health circular was issued, there was no official guidance on the establishment of hospital complaints procedures, and as a result these varied significantly from hospital to hospital. Even after the circular, much was left to local discretion: doctors handled complaints about other doctors, there was little or no external oversight and the complaint procedures themselves were not binding. 
Despite these difficulties, patients seemed to be becoming more willing to complain. The total number of written complaints investigated by hospital authorities in England and Wales rose from 7,984 in 1967 to 9,614 in 1971. This represented a slight rise from 1.59 complaints per 1,000 discharges in 1967 to 1.75 complaints per 1,000 discharges in $1971 .^{49}$ Furthermore, written complaints were likely to represent just a fraction of the total number of complaints made. Research in Scotland found that $25 \%$ of patients interviewed in hospital claimed to have made some sort of suggestion about 'desired improvements' ${ }^{50}$ The fact that few of these criticisms translated into formal complaints thus says rather more about hospital complaints procedures than unwillingness on the part of patients to complain.

The issue of patient complaints was given added impetus in the wake of a series of medical scandals in the late 1960s and early 1970s, which not only exposed poor quality care, but also the inadequacy of complaints procedures. The publication of Sans Everything: A Case to Answer by Barbara Robb and the organisation Aid for the Elderly in Government Institutions (AEGIS) presented a number of case studies of mistreatment of the elderly in NHS hospitals, but also pointed to the unsatisfactory state of complaints procedures. ${ }^{51}$ In 1969 , a Council of Tribunals report into the allegations made by Robb echoed her criticism of complaints procedures and called for 'radical revision' of the complaints investigation machinery. ${ }^{52}$ The need for reform of complaints procedures was further underscored by the report on the Ely Hospital scandal, also released in 1969. Two years earlier, British newspaper the News of the World printed allegations made by a nurse at Ely Hospital in Cardiff (a psychiatric institution) pointing to the mistreatment of patients, but also the suppression of complaints made by staff and patients' relatives and the victimisation of staff who did complain. The Ely report determined that the nurse's allegations 
were well-founded, and that a culture had been created at the hospital in which 'members of the nursing staff had been persuaded that it was useless, if not positively hazardous, to complain of matters which disturbed them. ${ }^{53}$ The report recommended that existing complaints procedures be reconsidered, and called for the establishment of an inspectorate for long-stay hospitals. ${ }^{54}$ The Ely scandal was followed quickly by another, this time in a hospital for the 'mentally handicapped', in Dorset. Once again, the subsequent report into conditions at the Farleigh Hospital (published in 1971) found that complaints were handled poorly, and the report's authors asserted that the existing system for dealing with complaints within the NHS was inadequate. ${ }^{55}$ A year later, yet another inquiry, this time into conditions at the Whittingham psychiatric hospital in Lancashire, discovered that complaints by staff were suppressed and that there was a failure to investigate other complaints. The report recommended that procedures for dealing with complaints from staff and patients be improved. ${ }^{56}$ Taken together, these reports demonstrated that existing complaints procedures were in need of radical overhaul. Although many of the scandals centred on the difficulties experienced by staff wishing to speak out about conditions, they also shined a light on the whole issue of complaints. The problem, it seemed, was not just confined to longstay hospitals. A coordinated, fair, open system for making complaints was required.

The task of providing guidance on the establishment of a complaints procedure was given to a governmental committee chaired by Sir Michael Davies, a barrister and later High Court judge. Established in 1971, the Davies Committee was made up of individuals from a diverse array of professional backgrounds, but what was particularly significant about the Committee's membership was that doctors and other health professionals were in a minority: of the 17 committee members just three were doctors. This mixed membership suggested a real willingness to investigate the 
complaints issue not just from the point of view of the doctor, but also from the perspective of the patient. This can also be seen in the way in which the Davies Committee conducted their investigation. They did hear from the various professional bodies and royal colleges, but the Committee also sought the views of a number of patient groups, including the PA and the National Association for the Welfare of Children in Hospital (NAWCH). ${ }^{57}$

The opinions of these organisations were reflected in the committee's final report. The Davies Committee was keen to place their findings within the context of growing consumerism. The report commented, 'This is an age in which the legitimate interests of the consumer, who in the hospital service is the patient, are rightly receiving increased protection in many fields $[\ldots]$ We see no reason why these general principles should not apply to the hospital service.' Moreover, the Davies Committee contended, 'Few [patients] have any serious grievances. But those who do have the legitimate right - no less - to have their dissatisfaction fully and fairly investigated. ${ }^{58}$ Such a strong statement suggested that complaints procedures would be strengthened considerably. Yet, the fate of the report tells a rather different story. Overall, the Davies Committee made 82 separate recommendations and proposed a complex and legalistic complaints procedure based on a tribunal system. They also separated out clinical and non-clinical complaints, leaving doctors to investigate allegations about medical mistakes. Despite this concession to professional selfregulation, the report was not well received among the medical community. The joint Medico-Legal Subcommittee of the Central Committee for Hospital Medical Services of the British Medical Association (BMA) and the Joint Consultants Committee (JCC) argued that the report implied that 'every encouragement be given to all citizens $[\ldots]$ to make a suggestion or complaint, not only when it is reasonable, but on 
any occasion, however trivial.' The effect of this atmosphere of complaining, they contended, would be 'to damage the service profoundly and to the detriment rather than to the advantage of the community in which it exists to serve. ${ }^{59}$ The Council of the BMA and the JCC told Sir Henry Yellowlees (the Chief Medical Officer) that "no part of the proposals put forward by the Davies Committee can be considered as acceptable to the medical profession until the considered view of the Association has been submitted. ${ }^{60}$

Despite the fact that the BMA had given evidence to the Davies Committee, doctors were obviously unhappy with its findings. In contrast, patient groups were broadly supportive. For example, the PA 'welcome[d] the constructive nature of the report and its sympathetic approach to the anxieties and preoccupations of patients. ${ }^{\prime 61}$ But the reception of the Davies report illustrated the relative lack of power of patient groups when compared to professional groups. The report, according to the sociologist Margaret Stacey, was met with 'thundering silence' and long delay. ${ }^{62}$ A draft code on hospital complaints procedure was produced in 1976, and this was followed by another consultation document in 1978. In 1981, a Department of Health circular was issued to all hospitals, but the complaints procedure was still a draft and not compulsory. It was not until 1985 and the passing of the Hospital Procedure Complaints Act, (12 years after Davies reported) that hospitals were actually required to have any sort of complaints procedure in place.

Moreover, even the creation of this piece of legislation was due to serendipity as much as design. As mentioned in the introduction to this chapter, the origins of the Hospital Complaints Procedure Act lay in a private member's bill, not a specific attempt by the government to introduce legislation on this issue. Most MPs, when given the chance to get their name on the statute books through the members' ballot, 
opted to put forward a technical piece of legislation that the government wished to see passed, but was not significant enough to be included in the main legislative programme. ${ }^{63}$ Much important legislation was passed through private members' bills, particularly on social and moral issues, like the Abortion Act (1967), but most of these bills resulted from pressure-group lobbying. However, this does not appear to have been the case with the Hospital Complaints Procedure Act: patient-consumer groups had no direct involvement in the creation of the Act. Instead, McNair-Wilson acted alone. Following months of hospitalisation, and a number of medical mishaps, McNair-Wilson published a 'Patient's Charter' which he hoped would redress the power imbalance between doctors and patients 'by laying down certain basic patients rights which will apply to every person. ${ }^{, 64}$ According to Linda Mulcahy, who interviewed McNair-Wilson before he died in 1993, the MP had wanted to use his bill to get his entire charter made into legislation, but the Secretary of State for Health told him that he would only get government backing if he selected just one clause from the charter to form a bill. ${ }^{65}$ McNair-Wilson chose the introduction of a complaints procedure; this was duly translated into legislation, and passed unopposed in February 1985. ${ }^{66}$ The Hospital Complaints Procedure Act required health authorities in England and Wales and health boards in Scotland to establish a complaints procedure and draw this to the attention of patients. ${ }^{67}$ The Department of Health drafted further guidelines on the complaints procedure, and this was finally issued to all hospitals in $1988 .{ }^{68}$

\section{Conclusions}


What does this tell us about complaints, rights, consumerism and the relationship between these? It might have been largely due to chance that the Hospital Complaints Procedure Act entered the statute books, but it is possible to argue that without the broader discussions about patient rights and complaining, and specifically the work of patient groups in producing patient guides and supporting complainants, McNairWilson would not have written his charter. Patient consumer groups helped produce a language of patients' rights that was then taken up by politicians, as can be seen in the later establishment of the Patient's Charter by the Department of Health in 1991 and the NHS Constitution in 2009, both of which feature the right to complain as a 'long established' patient right. ${ }^{69}$

Consumerism provided a discourse that drew attention to the rights of the individual and also, to some extent, of the collective, with respect to medical services. Being able to complain was a key facet of consumer identity, and as patients began to be seen as consumers, so the importance attached to complaints increased. But, this language only took patient-consumers so far. As the fate of the Davies report and the long-winded attempts to establish an organised hospital complaints procedure demonstrated, the tools provided by consumerism were insufficient in the face of more entrenched interests and powerful actors. The continued dominance of the medical profession, and the relative weakness of patient-consumer organisations when compared to professional groups, undermined attempts to introduce complaints procedures and strengthen patients' rights in this area.

Furthermore, issues remained around the effectiveness of rights claims. Even if we take the Hospital Complaints Procedure Act as giving the patient the right to complain, many patients continued (and continue) to find it difficult to complain. In 2008, a survey conducted by the PA revealed an NHS complaints system that, they 
said, was cumbersome, variable and took too long. ${ }^{70}$ Recent scandals over poor care within the NHS, such as at Stafford Hospital, demonstrate that complaining about medicine continues to be a highly contentious area. Even in the age of consumption, complaining about health care or treatment upsets the traditional doctor-patient relationship and power balance. By no longer being 'passive recipients', patientconsumers were challenging deep-seated assumptions about the contract formed between doctor and patient. ${ }^{71}$

Such a tension raises more fundamental questions about the meaning of consumption and the patient-consumer within a collective system like the NHS. As patients lacked what historian Roy Porter called the 'power of the purse', complaining and the wider discourse around patients' rights was one of the few tools available to patient groups. ${ }^{72}$ Rights held considerable rhetorical power, but they lacked legal or practical purchase. Underpinning this absence of applicability was a deeper level of uncertainty about who was complaining: was it the patient, citizen or consumer? This also had an impact on the nature of the rights that were being exercised: were these human rights, citizens' rights or consumers' rights? This was important, because different types of rights laid claim to different things, and were treated in slightly different ways. For example, as a citizen, a patient might assert his or her right to receive a certain service, but as a consumer, he or she might instead assert his or her right to choose a certain service. Without a clear basis or understanding of what kind of rights were being asserted, patient's rights claims were weak, sometimes conflicting, and left open to co-option by other actors.

Since the 1990s, the patients' rights agenda, and the interests of the patientconsumer, have been taken on by a succession of governments that tend to focus on the desires of the individual patient-consumer rather than the needs of patient- 
consumers plural. Gradual, but persistent, marketisation of the NHS under the Conservative, Labour and Coalition governments has resulted in the prioritisation of one right above all others: the right to choose. The difficulties surrounding choice in health have been much examined, but it is the coupling of rights and choice that would seem to have the most significant implications for a collective health system like the NHS. ${ }^{73}$ Indeed, if the right to choose has replaced the right to receive, then complaining about medicine would become more, not less important. Complaint may still have potential value as a collective tool, not just an individual one, as it could provide a way for patient-consumers to make their views heard. The possibilities offered by mechanisms such as the 'super-complaint', a sort of class action by complainants, and trialled in 2001 by the CA in the health care arena with respect to private dentistry, might provide ways to effect change on a grander scale. ${ }^{74}$ Perhaps, then, to really make a difference we should all moan less and complain more.

\footnotetext{
${ }^{1}$ House of Commons Debates, 22 February 1985 vol. 73 cc1370-86.

${ }^{2}$ House of Commons Debates, 22 February 1985 vol. 73 cc1370-86.

${ }^{3}$ Mark Jenner and Patrick Wallis (eds), Medicine and the Market in England and its Colonies, c.1450- c.1850 (Basingstoke: Palgrave, 2007); Roy Porter, 'The patient's view: doing medical history from below', Theory \& Society, 14, 2, (1985), pp. 17598; Martin Gorsky, 'Community involvement in hospital governance in Britain: evidence from before the National Health Service', International Journal of Health Services, 38, 4, (2008), pp. 751-771; Martin Gorsky and John Mohan with Tim Willis, Mutualism and Health Care: Hospital Contributory Schemes in Twentieth Century Britain (Manchester: Manchester University Press, 2006).

${ }^{4}$ D.S. Lees, Health Through Choice: An Economic Study of the British National Health Service (London: Institute of Economic Affairs, 1961); Political and Economic Planning (PEP), Family Needs and the Social Services (London: PEP, 1961); Research Institute for Consumer Affairs (RICA), General Practice a Consumer Commentary (London: RICA, 1963).

5 Anon, 'Patients as consumers: wants and needs', The Lancet, 277, 7183 (1961): pp. 927-28.

${ }^{6}$ Frank Trentmann, 'The modern genealogy of the consumer: meanings, identities and political synapses', in Frank Trentmann and John Brewer (eds), Consuming Cultures, Global Perspectives: Historical Trajectories, Transnational Exchanges (Oxford: Berg,
} 
2006), pp. 19-69; Matthew Hilton and Martin Daunton, 'Material politics: an introduction', in Daunton and Hilton (eds), The Politics of Consumption: Material Culture and Citizenship in Europe and America (Oxford: Berg, 2001), pp. 1-32. ${ }^{7}$ Matthew Hilton, Consumerism in Twentieth century Britain: the Search for a Historical Movement (Cambridge: Cambridge University Press, 2003).

${ }^{8}$ Similar developments were occurring in other countries at the same time. For the US, see Nancy Tomes, 'Patients or health-care consumers? Why the history of contested terms matters', in Rosemary A. Stephens, Charles E. Rosenberg and Lawton R. Burns, History and Health Policy in the United States: Putting the Past Back In (New Brunswick: Rutgers University Press, 2006), pp. 83-110.

${ }^{9}$ Maurice Pappworth, 'Human guinea pigs: a warning', Twentieth Century, 171, (1962), 67-75; Maurice Pappworth, Human Guinea Pigs: Experimentation on Man (London: Routledge \& Kegan Paul, 1967). For an historical account of these revelations, see Jenny Hazelgrove, 'The old faith and the new science: the Nuremberg code and human experimentation ethics in Britain, 1946-73', Social History of Medicine, 15, 1 (2002), pp. 109-35.

${ }^{10}$ Contemporary Medical Archives Centre (hereafter CMAC) Wellcome Library, London, SA/PAT/H/1 Press Cuttings Nov. 1962-Nov. 1963, Letter to the Sunday Times from Helen Hodgson, 25 Nov. 1962.

${ }^{11}$ Anon, '525 complaints on the NHS: need for change of staff attitude', Guardian, 4 September 1964, p. 5.

${ }^{12}$ Health Minister Keith Joseph in the House of Commons, House of Commons Debates, 19 June 1973, vol. 858, col. 380.

${ }^{13}$ ACHCEW CD Rom, Vol. 2, CHC News (January 1976) p. 8.

14 'Joining the queue for good health', March 1987. Press Release on South Birmingham CHC Annual Report, inserted into 1984-86 Annual Report; Gerrard, A Stifled Voice, p. 174.

${ }^{15}$ CMAC, SA/PAT/H/3, Anon., 'Patients complain', New Society, 10 September 1964; Letter from Helen Hodgson to the Sunday Telegraph, 7 February 1965.

${ }^{16}$ CMAC, SA/PAT/D/13/1, Patient Complaints - Patients Association Complaints Analysis Project 1976-1983.

${ }^{17}$ Glen O'Hara, 'The complexities of "consumerism": choice, collectivism and participation within Britain's National Health Service, c.1961-1979', Social History of Medicine, 26, 2 (2013) pp. 288-304, p. 298.

${ }^{18}$ Rudolf Klein, Complaints Against Doctors: A Study in Professional Accountability (London: Charles Knight, 1973).

${ }^{19}$ ACHCEW CD Rom, Vol. 2, CHC News (January 1976) p. 8.

${ }^{20}$ Jack Hallas and Bernadette Fallon, Mounting the Health Guard: A Handbook for Community Health Council Members (Oxford: Nuffield Provincial Hospitals Trust, 1974) p. 31.

${ }^{21}$ Klein, Complaints against Doctors, p. 104.

${ }^{22}$ CMAC SA/PAT/A/1/6, Elizabeth Stanton, 'Patients' rights and responsibilities', The Clapham Omnibus, 11 (Winter 1981).

${ }^{23}$ ACHCEW CD Rom, Vol. 2, CHC News (May 1976), p. 1.

${ }^{24}$ Levitt quoted in Gerrard, A Stifled Voice, p. 229.

${ }^{25}$ Royal Commission on the NHS, Report, p. 155.

${ }^{26}$ Lynn Hunt, Inventing Human Rights: A History (New York: WW Norton \& Co., 2007); Micheline R. Ishay, The History of Human Rights: From Ancient Times to the Globalization Era (Berkeley: University of California Press, 2004); Dorothy Porter, 
Health Civilization and the State: A History of Public Health From Ancient to Modern Times (London: Routledge, 1999), 57. See also Clarke's Afterword.

${ }^{27}$ United Nations, Universal Declaration of Human Rights, Article 25 (1948).

${ }^{28}$ World Health Organization, Constitution of the World Health Organization, (1946). Available from http://www.who.int/governance/eb/who_constitution_en.pdf, accessed 15 July 2011. United Nations, International Covenant on Economic, Social and Cultural Rights (1966/1976). Available from http://www2.ohchr.org/english/law/pdf/cescr.pdf accessed 15 July 2011.

${ }^{29}$ Declaration of Alma Ata: International Conference on Primary Health Care, USSR, September 1978.

${ }^{30}$ Anne-Emmanuelle Birn, 'Special section - health and human rights: historical perspectives and political challenges', Journal of Public Health Policy, 29 (2008), pp. 32-41; Daniel Tarantola, 'A perspective on the history of health and human rights: from the Cold War to the Gold War', Journal of Public Health Policy, 29 (2008), pp. 42-53; Stephen P. Marks, 'The evolving field of health and human rights: issues and methods', Journal of Law, Medicine and Ethics, 30 (2002), pp. 732-54; Kenneth Cmiel, 'The recent history of human rights', American Historical Review, 109, 1 (2004), pp. 117-135.

${ }^{31}$ See, for example, Catherine Crawford, 'Patients' rights and the law of contract in eighteenth century England', Social History of Medicine, 13, 3 (2000), pp. 381-410.

${ }^{32}$ Martin Gorsky, 'Community involvement in hospital governance in Britain: evidence from before the National Health Service', International Journal of Health Services, 38, 4 (2008), pp. 751-71.

${ }^{33}$ NHS Act, 1946.

${ }^{34}$ The New National Health Service, 1948. Quoted in Charles Webster, The National Health Service: A Political History (Oxford: Oxford University Press, 2002), p. 24. ${ }^{35}$ T. H. Marshall, 'Citizenship and Social Class', in T. H. Marshall and Tom Bottomore (eds), Citizenship and Social Class (London: Pluto Press, 1992), pp. 3-51. ${ }^{36}$ On the 'classic' welfare state, see Rodney Lowe, The Welfare State in Britain since 1945 (Basingstoke: Palgrave Macmillan, 2005).

${ }^{37}$ See, for example, Frank Trentmann, 'Citizenship and consumption', Journal of Consumer Culture, 7, 2 (2007), pp. 147-58; Frank Trentmann and Vanessa Taylor, 'From Users to Consumers: Water Politics in Nineteenth-Century London', in Frank Trentmann (ed.), The Making of the Consumer: Knowledge, Power and Identity in the Modern World (Oxford: Berg, 2005), pp. 53-79.

${ }^{38}$ On consumerism and housing, see Peter Shapely, 'Tenants arise! Consumerism, tenants and the challenge to council authority in Manchester, 1968-92', Social History, 31, 1 (2006), pp. 60-78.

${ }^{39}$ Hazelgrove, 'The old faith in the new science'; David J. Rothman, Strangers at the Bedside: A History of How Law and Bioethics Transformed Medical Decision Making (New York: Basic Books, 1991), pp. 61-63.

${ }^{40}$ Hodgson quoted in Anon, 'Now a voice for patients', The Times, 17 June 1963, 15.

${ }^{41}$ Helen Hodgson, 'Medical ethics and controlled trials', letter to the British Medical Journal, 18 May 1963, 1339-40.

42 Shelia Rowbotham, 'Introduction' to Helene Curtis and Mimi Sanderson, The Unsung Sixties: Memoirs of Social Innovation (London: Whiting \& Birch, 2004), pp. ix-xii, p. xi.

43 Jürgen Habermas, 'New social movements', Telos, 49 (1981), pp. 33-37. 
${ }^{44}$ Patients Association, Can I Insist? (London: Patients Association, 1974); Which, Guide to Your Rights (London: Consumers Association, 1980); Consumers' Association/Patients Association, A Guide to the National Health Service (London: Consumers' Association, 1983); National Consumer Council, Patients' Rights: A Guide for NHS Patients and Doctors (London: HMSO, 1983); ACHCEW, Patients' Charter: Guidelines for Good Practice (London: ACHCEW, 1986).

${ }^{45}$ NCC, Patients' Rights, p. 5.

${ }^{46}$ Consumers' Association, The Which? Guide to Your Rights, p. 9.

${ }^{47}$ Margaret Stacey, Regulating British Medicine: The General Medical Council (Chichester: John Wiley and Sons, 1992), p. 56.

${ }^{48}$ Klein, Complaints Against Doctors, page?.

${ }^{49}$ Stacey, Regulating British Medicine, p. 17.

${ }^{50}$ DHSS, Report of the Committee on Hospital Complaints Procedure (London: HMSO, 1973), p. 7.

${ }^{51}$ Barbara Robb, Sans Everything: A Case to Answer (London: Nelson, 1967).

${ }^{52}$ Council on Tribunals, The Annual Report of the Council on Tribunals 1968 (London: HMSO, 1969) p. 10.

${ }^{53}$ Cmnd. 3975, Report of the Committee of Inquiry into Allegations of Ill-Treatment of Patients and Other Irregularities at the Ely Hospital, Cardiff, (London: HMSO, 1969) p. 73.

${ }^{54}$ Ibid. p. 132.

${ }^{55}$ Cmnd. 4557, Report of the Farleigh Hospital Committee of Inquiry (London: HMSO, 1971) p. 23.

${ }^{56} \mathrm{Cmnd} .4861$, Report of the Committee of Inquiry into Whittingham Hospital (London: HMSO, 1972) p. 42.

${ }^{57}$ DHSS, Report of the Committee on Hospital Complaints.

${ }^{58}$ Ibid., 4.

${ }^{59}$ TNA MH 159/281, Hospital Complaints Procedure: The Report of the Davies Committee - Report of the Joint Medico-Legal Subcommittee to the CCHMS and JCC, nd. [April 1974?].

60 TNA MH 159/281, Elston Grey-Turner, Deputy Secretary of the BMA to Dr H Yellowlees (CMO) 25 April 1974.

${ }^{61}$ TNA MH 159/281, The Patients Association: Comment on Report of the Committee on Hospitals Complaints Procedure, March 1974.

${ }^{62}$ Modern Records Centre, University of Warwick, MSS.184 Box 2: The NHS Complaints Procedure Three Years On: Opening Address by Meg Stacey.

${ }^{63}$ David Marsh and Melvyn Read, Private Members' Bills (Cambridge: Cambridge University Press, 1988), p. 42.

${ }^{64}$ McNair-Wilson's charter was published by ACHCEW. See ACHCEW Health News Briefing, 19 November 1984, The Patient's Charter. From the CD-Rom "The Golden Age of Patient and Public Involvement: Celebrating the Work of Community Health Councils, 1974-2003, Vol. 2", available from the Wellcome Library, London. ${ }^{65}$ Mulcahy, Disputing Doctors, p. 41.

${ }^{66}$ See House of Commons Debates 22 February 1985 vol. 73 cc1370-86.

${ }^{67}$ Hospital Complaints Procedure Act, 1985.

${ }^{68}$ Mulcahy, Disputing Doctors, p. 41.

${ }^{69}$ Department of Health, Patient's Charter (London: HMSO, 1991); Department of Health, The NHS Constitution (London: Department of Health, 2009). 
${ }^{70}$ Patients Association, NHS Complaints: Who cares? Who can Make it Better? (London: Patients Association, 2008).

${ }^{71}$ See, for example, discussion of the implications of the Francis Report on the conditions at Stafford Hospital and what this means for patient complaint mechanisms, eg. Adrian O'Dowd, 'BMJ round table: after Francis, what next for the NHS?' British Medical Journal (10 April 2013), 346, f2074, pp. 1-3.

${ }^{72}$ Porter, 'The patient's view', p. 189.

${ }^{73}$ See, for example, John Clarke, Nicholas Smith and Elizabeth Vidler, 'The indeterminacy of choice: political, policy and organisational implications', Social Policy and Society, 5, 3 (2006), pp. 327-36; John Appleby, Anthony Harrison and Nancy Devlin, What is the Real Cost of More Patient Choice? (London: King's Fund, 2003); Which?, Which Choice? Health (London: Which?, 2005).

${ }^{74}$ Celia Hall, 'Super complaint on private dentists', The Daily Telegraph, 30 October 2001. Available from: http://www.telegraph.co.uk/news/uknews/1360904/Supercomplaint-on-private-dentists.html 